\title{
Main and rare earth elements of amphibolites of the Ray-Iz massif (Polar Urals)
}

\author{
Alyona Romanovna BOGDANOVA ${ }^{1 *}$, \\ Nadezhda Vladimirovna VAKHRUSHEVA ${ }^{1,2 * *}$, \\ Pavel Borisovich SHIRYAEV ${ }^{1,2 * * *}$
}

${ }^{1}$ The Zavaritsky Institute of Geology and Geochemistry of the Ural Branch of RAS, Ekaterinburg, Russia ${ }^{2}$ Ural State Mining University, Ekaterinburg, Russia

\section{Abstract}

Relevance. The Ray-Iz massif contains the Tsentralnoye chromium ore deposit and is unique in terms of variety of metamorphic rock associations. It has been studied since 1932. However, some aspects of geology and petrology in the literature are not fully covered. One of these areas is a vein series of rocks localized in ultramafic rocks. The spatial confinement of amphibolites to the Central zone of metamorphism, which is consistent with the zone of distribution of deposits and ore occurrences of chromites, determines the need for a detailed study.

Purpose of work. Study of mineralogical and petrographic characteristics, as well as the geochemistry of lanthanides of amphibolites of the Ray-Iz massif (Polar Urals).

Results. The study of the nature of REE distribution in rock-forming minerals made it possible to determine that the variation in the amount of REE (33-75 g/t) within one rock is associated with the quantitative content of the main minerals-concentrators. The main mineral concentrator lanthanides in garnet amphibolites is garnet, while amphibole is in garnet-free pyroxene-bearing amphibolites. Based on the results of the chemical composition of amphibole and coexisting plagioclases and amphibolite garnets, the temperature was calculated using amphiboleplagioclase by T. Holland, J. Blundy, as well as the garnet amphibolite by L. L. Perchuk geothermometers and pressure based on amphibole geobarometer by M. W. Schmidt.

Conclusion. The nature of the distribution of lanthanides in the main rock-forming minerals, amphibole and garnet, has been revealed. Comparison of parameters and compositional features of amphiboles made it possible to conclude that there is a direct relationship between temperature, pressure, the sum of $\mathrm{REE}$ and $\mathrm{TiO}_{2}$, as well as $(\mathrm{La} / \mathrm{Yb})_{\mathrm{n}}$, in the mineral.

Keywords: amphibole, amphibolite, REE geochemistry, Central zone of metamorphism, Ray-Iz, Polar Urals.

\section{Introduction}

The Ray-Iz ultramafic massif forms the northern end of the Main ultramafic belt of the Urals and is one of the largest massifs in the Urals [1]. The massif contains the Tsentralnoye chromium ore deposit and is unique in terms of the variety of rock metamorphic associations. It has been studied since 1932 [2]. Later, many researchers were engaged in its study (E.P. Tsaritsyn [3]; Yu.E. Moldavantsev [4]; A. B. Makeev [5]; Chashchukhin [6]; V. N. Puchkov [7]; Perevozchikov [3]; and others). However, some aspects of geology and petrology are not fully covered in the literature. One of these areas is a vein series of rocks localized in ultramafic rocks.

This paper discusses the results of studying the mineralogical and petrographic characteristics, as well as the geochemistry of lanthanides of amphibolites of the Ray-Iz massif.

Amphibolites, along with sagvandites and enstatite-olivine rocks, compose the so-called Central Metamorphism Zone (CMZ) of the Ray-Iz massif, which stretches in a sublatitudinal direction along the Levaya Makar-Ruz river to the head of the Enga-Yu river [8]; amphibolites are exposed in the walls of cirques on the left bank of the Levaya Makar-Ruz river. The central zone of metamorphism is manifested in the form of a linear strip and is located at the junction of two large tectonic blocks identified by geophysical data: the northern one with a thickness of $1.0-1.5 \mathrm{~km}$, and the southern one with a thickness of up to $6 \mathrm{~km}$. The zone represents the most prominent axial part (subjected to high-temperature transformations) of an extended band of metamorphism and deformations, which captured the main part of the massif $[7,8]$. It is assumed that CMZ coincides with the zone of deep fault, delimiting the area of maximum uplift of "basalts" from the Precambrian basement [4].

\section{Chemical composition of amphibolites}

Despite the fact that the studied amphibolites compose a geologically unified body, they differ in structure, mineral composition, quantity and size of garnet, as well as in the content of the main petrogenic elements. 

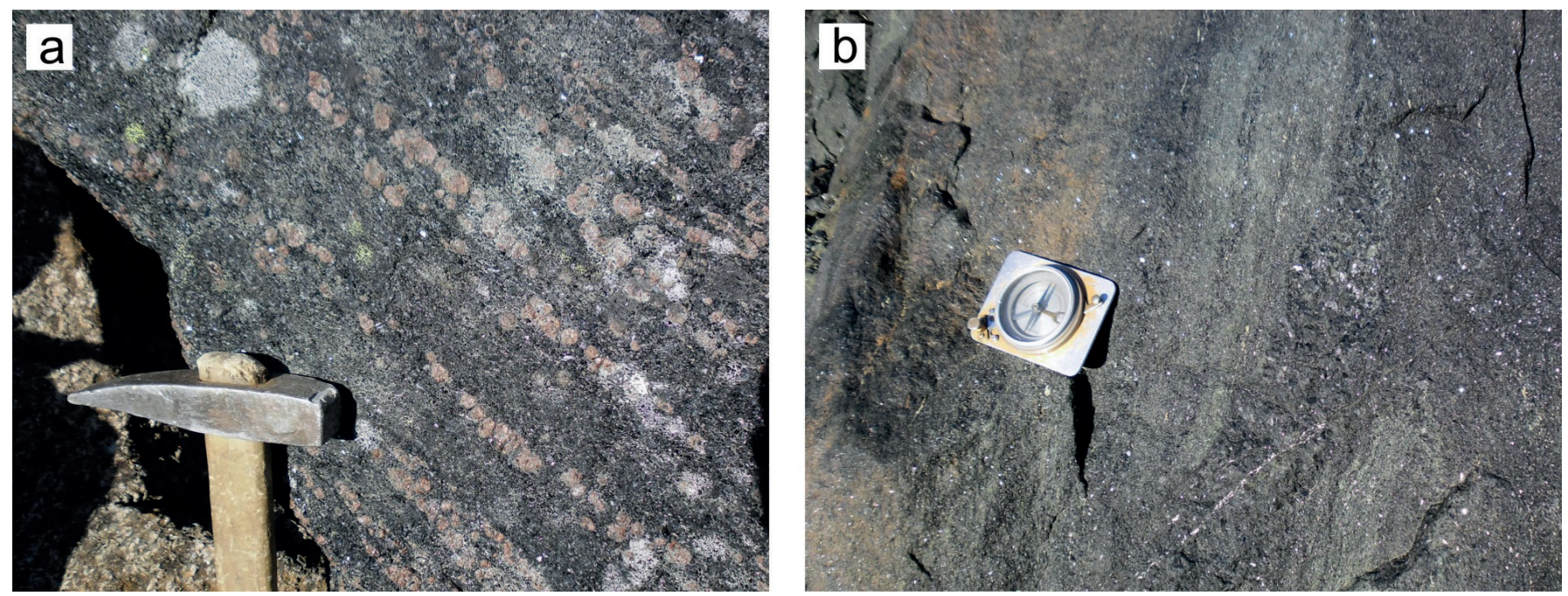

Figure 1. Types of amphibolites of the Ray-Iz massif, photographs of outcrops. a - coarse-grained garnet amphibolite (sam. Y-3533/1); $b$ medium-grained garnet-free pyroxene-bearing amphibolite (Y-3536/4).

Рисунок 1. Типы амфиболитов массива Рай-Из, фотографии обнажений: а - крупнозернистый гранатовый амфиболит (обр. Y-3533/1); b - среднезернистый безгранатовый пироксенсодержащий амфиболит (Y-3536/4).
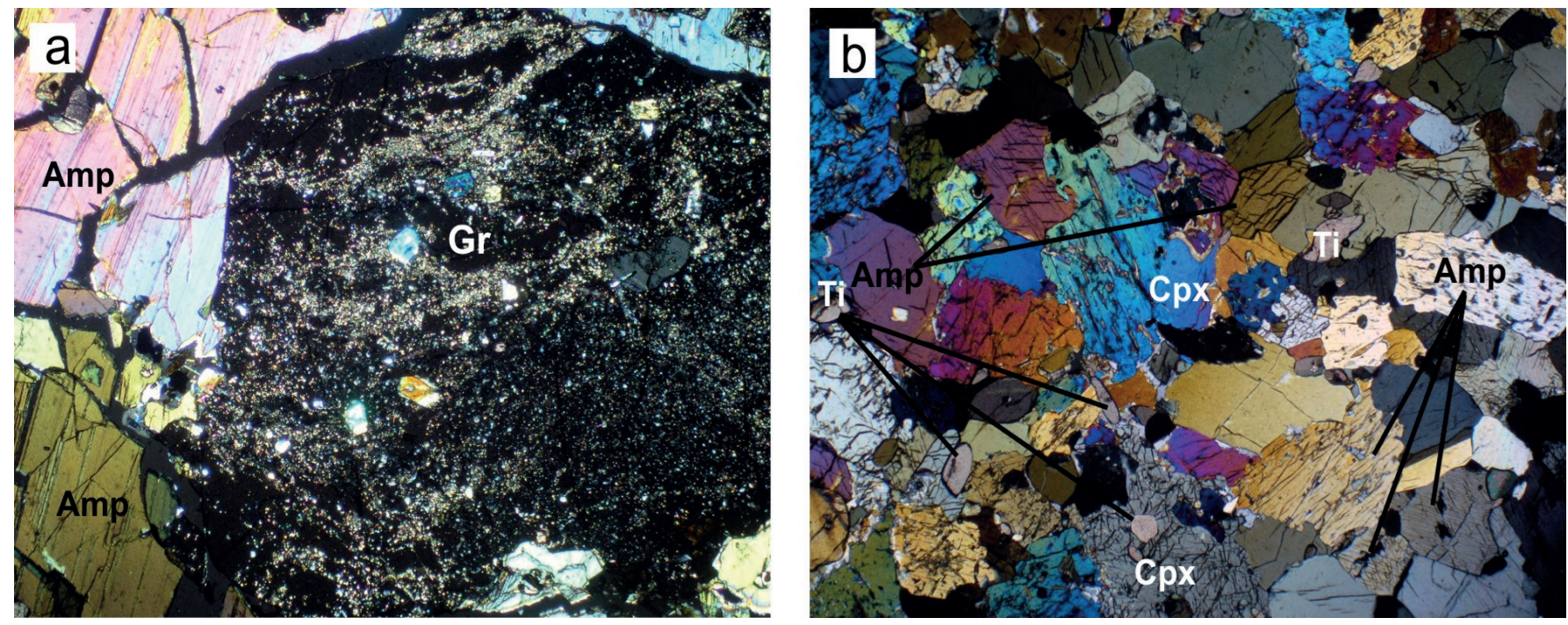

Figure 2. Types of amphibolites of the Ray-lz massif, photographs of thin sections. a - coarse-grained garnet amphibolite (sam. Y-3533/1); b - medium-grained garnet-free pyroxene-bearing amphibolite (Y-3536/4). Amp - amphibole, Cpx - clinopyroxene, Gr - garnet, Ti - titanite

Рисунок 2. Типы амфиболитов массива Рай-Из, фотографии шлифов: а - крупнозернистый гранатовый амфиболит (обр. Y-3533/1); $\mathrm{b}$ - среднезернистый безгранатовый пироксенсодержащий амфиболит (Y-3536/4). Amp - амфибол, Cpx - клинопироксен, Gr - гранат, Ті - титанит.

Coarse-grained garnet amphibolites (Y-3533/1, Y-3536/1) are characterized by a porphyroblastic/poikiloblastic structure. The base is composed mainly of dark green to greenish-black amphibole (70-75\%), rounded garnet porphyroblasts (10-15\%) of brownish-red color, reaching $3 \mathrm{~cm}$ in diameter. Porphyroblasts are unevenly distributed in the rock, with the formation of linear zones and "chains" (Fig. 1, a; 2, a). Poikilite intergrowths in garnet are represented by amphibole, plagioclase, and titanite.

The bodies of garnet amphibolites contain zones composed of medium-grained, garnet-free pyroxene-amphibole rocks (Y-3533/3, Y-3536/4) (Fig. 1, b; 2, b). Clinopyroxene is represented by diopside, the content of which reaches 35$40 \%$. Amphibole is $50-55 \%$, epidote is noted in a subordinate amount (1-2\%). The zones of garnet-free pyroxene-amphibole rocks have a lenticular shape and a thickness of $10-15 \mathrm{~cm}$ with a length of $50-70 \mathrm{~cm}$.

Medium-grained, homeoblastic garnet amphibolites (Y-3536/3) are also found, in which garnet grains are evenly distributed and do not exceed $1 \mathrm{~mm}$ in diameter. The main rock-forming minerals of the rock are amphibole (65-70\%), epidote (10-15\%), and garnet (10-15\%).

Clinozoisite $(2-3 \%)$ and plagioclase $(<1 \%)$ are present in all the above-mentioned samples in subordinate amounts. Rutile, titanite, and zircon are observed as accessories (1-3\%).

The study of the ratio of the main petrogenic elements showed that in the diagram $\left(\mathrm{Na}_{2} \mathrm{O}+\mathrm{K}_{2} \mathrm{O}\right)-\mathrm{SiO}_{2}$ (Fig. 3), the points of the amphibolite compositions are confined to the 
fields of rock compositions of both moderate and normal alkalinity and lie in the picro-basalt field.

The chemical compositions of minerals were investigated using the Cameca SX 100 electron probe microanalyzer at the Zavaritsky Institute of Geology and Geochemistry, the Common Use Center of the Ural Branch of the Russian Academy of Sciences "Geoanalyst"; analysts I. A. Danilenko, D. A. Zamyatin.

For the studied amphibolites, a variation in the chemical composition of the amphibole was identified. According to the modern classification of calcium amphiboles [10,11], amphibole from garnet amphibolite corresponds to edenite and the most highly parametric pargasite. The grains show chemical zoning - the rim parts are the most enriched in $\mathrm{Al}_{2} \mathrm{O}_{3}, \mathrm{Cr}_{2} \mathrm{O}_{3}$, $\mathrm{FeO}$ relative to the central ones (Table 1). Garnet is characterized by a high content of almandine $(52-57 \%)$, moderate grossular (30-32\%) and low pyrope (10-13\%) components. Garnet grains have a zonal structure with a fall in $\mathrm{MnO}$ from 1.95 to $0.6 \mathrm{wt}$. \% (spessartine component) to the rim of the grain (Table 4). Plagioclase corresponds to oligoclase $\mathrm{An}_{18,6}$ $\mathrm{An}_{20,9}$ (Table 2).

The amphibole from garnet-free pyroxene-bearing amphibolites corresponds to edenite. Chemical zoning is shown in the depletion of the marginal parts of $\mathrm{Al}_{2} \mathrm{O}_{3}$ and $\mathrm{FeO}$ grains relative to the central ones (Table 1). Pyroxene, according to the classification diagram of $\mathrm{Ca}-\mathrm{Mg}-\mathrm{Fe}$ pyroxenes [12], corresponds to diopside with an increased content of $\mathrm{Na}_{2} \mathrm{O}(1.51-$ 2.63 wt.\%) (Table 3). Plagioclase corresponds to oligoclase $\mathrm{An}_{11.6}-\mathrm{An}_{15.2}$ (Table 2).

The chemical composition of amphiboles of these samples makes it possible to judge about different gradients of metamorphism within the CMZ - in the first case, zoning is characteristic of progressive metamorphism, in the second, for regressive metamorphism.

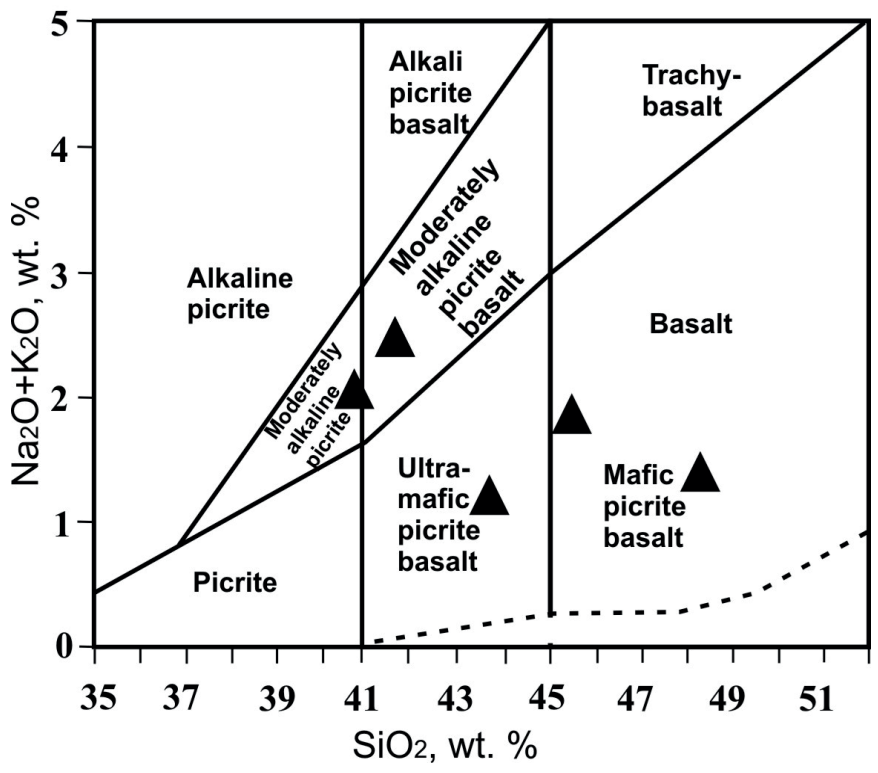

Figure 3. Fragment of the TAS diagram $\left(\mathrm{Na}_{2} \mathrm{O}+\mathrm{K}_{2} \mathrm{O}\right)-\mathrm{SiO}_{2}$ for the chemical classification of magmatic (volcanic) rocks [9] with the placement of the points of amphibolite compositions.

Рисунок 3. Фрагмент TAS-диаграммы $\left(\mathrm{Na}_{2} \mathrm{O}+\mathrm{K}_{2} \mathrm{O}\right)-\mathrm{SiO}_{2}$ для химической классификации магматических (вулканических) горных пород [9] с вынесением точек составов амфиболитов.

Features of the trace element composition of rock-forming minerals

Distribution of rare earth elements in garnets and amphiboles from various metamorphic associations is covered in a number of publications [13-15].

The content of lanthanides was analyzed in 5 amphibolite samples by the ICP-MS ELAN-9000 method at the Zavaritsky

Table 1. Chemical composition of amphibole from amphibolites, wt. \%.

Таблица 1. Химический состав амфибола из амфиболитов, мас. \%.

\begin{tabular}{|c|c|c|c|c|c|c|c|c|c|c|c|c|}
\hline $\begin{array}{l}\text { Number } \\
\text { of sample }\end{array}$ & Grain-point & $\mathrm{SiO}_{2}$ & $\mathrm{TiO}_{2}$ & $\mathrm{Al}_{2} \mathrm{O}_{3}$ & $\mathrm{Cr}_{2} \mathrm{O}_{3}$ & $\mathrm{FeO}$ & $\mathrm{MgO}$ & $\mathrm{MnO}$ & $\mathrm{CaO}$ & $\mathrm{Na}_{2} \mathrm{O}$ & $\mathrm{K}_{2} \mathrm{O}$ & Total \\
\hline \multirow{4}{*}{ Y-3533/1 } & $2-17 r$ & 40.48 & 0.83 & 15.82 & 0.05 & 17.86 & 7.65 & 0.17 & 10.15 & 3.19 & 0.51 & 96.71 \\
\hline & $2-18 c$ & 41.16 & 0.97 & 15.17 & 0.02 & 17.45 & 8.01 & 0.18 & 9.92 & 3.42 & 0.53 & 96.83 \\
\hline & $4-48 r$ & 41.47 & 1.06 & 15.04 & 0.02 & 17.7 & 8.60 & 0.13 & 10.42 & 3.19 & 0.47 & 98.10 \\
\hline & $4-49 c$ & 41.51 & 0.92 & 14.51 & 0.04 & 17.3 & 8.79 & 0.30 & 10.29 & 3.01 & 0.47 & 97.14 \\
\hline \multirow{4}{*}{ Y-3536/4 } & $1-9 r$ & 43.79 & 0.77 & 11.78 & 0.06 & 13.95 & 11.35 & 0.18 & 10.89 & 2.87 & 0.58 & 96.22 \\
\hline & $1-8 c$ & 43.67 & 0.71 & 11.80 & 0.04 & 14.35 & 11.52 & 0.23 & 11.23 & 2.84 & 0.54 & 96.93 \\
\hline & $2-1 r$ & 44.78 & 0.49 & 10.82 & 0.04 & 14.55 & 12.11 & 0.27 & 11.58 & 2.49 & 0.37 & 97.50 \\
\hline & $2-2 c$ & 43.96 & 0.77 & 11.63 & 0.03 & 14.57 & 11.26 & 0.13 & 11.34 & 2.60 & 0.51 & 96.80 \\
\hline \multicolumn{13}{|c|}{ Formula coefficients (calculation based on 23 oxygen atoms) } \\
\hline $\begin{array}{l}\text { Number } \\
\text { of sample }\end{array}$ & Grain-point & $\mathrm{Si}$ & $\mathrm{Ti}$ & Allv & $\mathrm{Al}^{\mathrm{VI}}$ & $\mathrm{Cr}$ & $\mathrm{Fe}$ & $\mathrm{Mg}$ & $\mathrm{Mn}$ & $\mathrm{Ca}$ & $\mathrm{Na}$ & $\mathrm{K}$ \\
\hline \multirow{4}{*}{ Y-3533/1 } & $2-17 r$ & 6.165 & 0.095 & 1.835 & 1.005 & 0.006 & 2.275 & 1.737 & 0.022 & 1.656 & 0.942 & 0.099 \\
\hline & $2-18 c$ & 6.245 & 0.111 & 1.755 & 0.958 & 0.002 & 2.214 & 1.812 & 0.023 & 1.613 & 1.006 & 0.103 \\
\hline & $4-48 r$ & 6.216 & 0.119 & 1.784 & 0.873 & 0.002 & 2.219 & 1.922 & 0.017 & 1.673 & 0.927 & 0.090 \\
\hline & $4-49 c$ & 6.274 & 0.105 & 1.726 & 0.859 & 0.005 & 2.187 & 1.981 & 0.038 & 1.666 & 0.882 & 0.091 \\
\hline \multirow{4}{*}{ Y-3536/4 } & $1-9 r$ & 6.574 & 0.087 & 1.426 & 0.659 & 0.007 & 1.752 & 2.540 & 0.023 & 1.752 & 0.835 & 0.111 \\
\hline & $1-8 c$ & 6.530 & 0.080 & 1.470 & 0.609 & 0.005 & 1.795 & 2.568 & 0.029 & 1.799 & 0.823 & 0.103 \\
\hline & $2-1 r$ & 6.646 & 0.055 & 1.354 & 0.538 & 0.005 & 1.806 & 2.679 & 0.034 & 1.841 & 0.716 & 0.070 \\
\hline & $2-2 c$ & 6.576 & 0.087 & 1.424 & 0.627 & 0.004 & 1.823 & 2.511 & 0.016 & 1.818 & 0.754 & 0.097 \\
\hline
\end{tabular}

Note: $r$ - grain rim, $c$ - grain center. 
Table 2. Chemical composition of plagioclase from amphibolites, wt. \%.

Таблица 2. Химический состав плагиоклаза из амфиболитов, мас. \%.

\begin{tabular}{|c|c|c|c|c|c|c|c|c|c|c|c|c|c|c|}
\hline $\begin{array}{l}\text { Number } \\
\text { of sam- } \\
\text { ple }\end{array}$ & $\begin{array}{l}\text { Grain- } \\
\text { point }\end{array}$ & $\mathrm{SiO}_{2}$ & $\mathrm{TiO}_{2}$ & $\mathrm{Cr}_{2} \mathrm{O}_{3}$ & $\mathrm{Al}_{2} \mathrm{O}_{3}$ & $\mathrm{FeO}$ & $\mathrm{MgO}$ & $\mathrm{MnO}$ & $\mathrm{CaO}$ & $\mathrm{Na}_{2} \mathrm{O}$ & $\mathrm{K}_{2} \mathrm{O}$ & $\mathrm{SrO}$ & $\mathrm{Ni}$ & Total \\
\hline & $6-76$ & 62.87 & 0.00 & 0.00 & 22.90 & 0.08 & 0.00 & 0.05 & 4.06 & 9.62 & 0.05 & 0.29 & 0.00 & 99.92 \\
\hline \multirow[t]{3}{*}{ Y-3533/1 } & $2-98$ & 62.80 & 0.02 & 0.02 & 22.91 & 0.12 & 0.01 & 0.01 & 4.09 & 9.42 & 0.05 & 0.41 & 0.00 & 99.86 \\
\hline & $2-99$ & 63.13 & 0.00 & 0.00 & 22.75 & 0.20 & 0.00 & 0.00 & 4.08 & 9.73 & 0.04 & 0.36 & 0.00 & 100.29 \\
\hline & $4-9$ & 64.82 & 0.00 & 0.04 & 22.10 & 0.15 & 0.00 & 0.00 & 2.99 & 9.81 & 0.02 & 0.00 & 0.04 & 99.97 \\
\hline \multirow[t]{2}{*}{ Y-3536/4 } & $5-1$ & 65.16 & 0.01 & 0.00 & 22.05 & 0.21 & 0.01 & 0.01 & 2.87 & 10.01 & 0.02 & 0.07 & 0.02 & 100.44 \\
\hline & $1-7$ & 64.06 & 0.00 & 0.13 & 22.14 & 0.15 & 0.00 & 0.00 & 3.11 & 10.08 & 0.04 & 0.18 & 0.01 & 99.89 \\
\hline \multicolumn{15}{|c|}{ Formula coefficients (calculation for 5 cations) } \\
\hline \multirow[t]{2}{*}{$\begin{array}{c}\text { Number } \\
\text { of sam- } \\
\text { ple }\end{array}$} & $\begin{array}{l}\text { Grain- } \\
\text { point }\end{array}$ & Si & $\mathrm{Ti}$ & $\mathrm{Cr}$ & $\mathrm{Al}$ & $\mathrm{Fe}$ & $\mathrm{Mg}$ & $\mathrm{Mn}$ & $\mathrm{Ca}$ & $\mathrm{Na}$ & $\mathrm{K}$ & $\mathrm{Sr}$ & $\mathrm{Ni}$ & An, $\%$ \\
\hline & $6-76$ & 2.777 & 0.000 & 0.000 & 1.192 & 0.003 & 0.000 & 0.00 & 0.192 & 0.824 & 0.003 & 0.007 & 0.000 & 20.0 \\
\hline \multirow[t]{3}{*}{ Y-3533/1 } & $2-98$ & 2.781 & 0.001 & 0.001 & 1.196 & 0.004 & 0.001 & 0.00 & 0.194 & 0.809 & 0.003 & 0.011 & 0.000 & 20.5 \\
\hline & 2-99 & 2.778 & 0.000 & 0.000 & 1.180 & 0.007 & 0.000 & 0.00 & 0.192 & 0.830 & 0.002 & 0.009 & 0.000 & 20.2 \\
\hline & $4-9$ & 2.860 & 0.000 & 0.000 & 1.141 & 0.008 & 0.001 & 0.00 & 0.135 & 0.852 & 0.001 & 0.002 & 0.001 & 14.1 \\
\hline \multirow[t]{2}{*}{ Y-3536/4 } & $5-1$ & 2.956 & 0.001 & 0.000 & 1.044 & 0.008 & 0.001 & 0.00 & 0.052 & 0.935 & 0.002 & 0.002 & 0.000 & 13.7 \\
\hline & $1-7$ & 2.824 & 0.000 & 0.005 & 1.150 & 0.006 & 0.000 & 0.00 & 0.147 & 0.862 & 0.002 & 0.005 & 0.000 & 15.2 \\
\hline
\end{tabular}

Note. An - anorthite molecule.

Table 3. Chemical composition of pyroxene from amphibolite, wt. \%.

Таблица 3. Химический состав пироксена из амфиболита, мас. \%.

\begin{tabular}{|c|c|c|c|c|c|c|c|c|c|c|c|c|c|}
\hline $\begin{array}{l}\text { Number } \\
\text { of sample }\end{array}$ & Grain-point & $\mathrm{SiO}_{2}$ & $\mathrm{MgO}$ & $\mathrm{CaO}$ & $\mathrm{Cr}_{2} \mathrm{O}_{3}$ & $\mathrm{FeO}$ & $\mathrm{MnO}$ & $\mathrm{NiO}$ & $\mathrm{Al}_{2} \mathrm{O}_{3}$ & $\mathrm{Na}_{2} \mathrm{O}$ & $\mathrm{K}_{2} \mathrm{O}$ & $\mathrm{TiO}_{2}$ & Total \\
\hline \multirow{14}{*}{ Y-3536/4 } & $1-4 r$ & 52.88 & 11.79 & 21.58 & 0.04 & 8.29 & 0.21 & 0.00 & 2.97 & 1.89 & 0.00 & 0.18 & 99.83 \\
\hline & $1-5 c$ & 53.15 & 11.83 & 21.6 & 0.05 & 8.38 & 0.22 & 0.04 & 2.76 & 1.86 & 0.00 & 0.06 & 99.95 \\
\hline & $2-6 c$ & 53.07 & 12.06 & 22.6 & 0.01 & 8.37 & 0.28 & 0.00 & 2.18 & 1.51 & 0.00 & 0.13 & 100.21 \\
\hline & $3-8 r$ & 53.31 & 11.59 & 21.27 & 0.03 & 8.38 & 0.2 & 0.01 & 3.21 & 2.19 & 0.00 & 0.10 & 100.29 \\
\hline & $3-9 c$ & 53.02 & 11.98 & 22.4 & 0.19 & 8.67 & 0.27 & 0.03 & 2.17 & 1.55 & 0.01 & 0.05 & 100.34 \\
\hline & $3-10 r$ & 52.82 & 12.19 & 22.56 & 0.00 & 8.72 & 0.26 & 0.00 & 2.46 & 1.64 & 0.00 & 0.15 & 100.80 \\
\hline & \multicolumn{13}{|c|}{ Formula coefficients (calculation for 4 cations) } \\
\hline & Grain-point & $\mathrm{Si}$ & $\mathrm{Mg}$ & $\mathrm{Ca}$ & $\mathrm{Cr}$ & $\mathrm{Fe}$ & $\mathrm{Mn}$ & $\mathrm{Ni}$ & $\mathrm{Al}$ & $\mathrm{Na}$ & $\mathrm{K}$ & $\mathrm{Ti}$ & $f$ \\
\hline & $1-4 \mathrm{r}$ & 1.958 & 0.651 & 0.856 & 0.001 & 0.257 & 0.007 & 0.000 & 0.13 & 0.136 & 0.00 & 0.005 & 28.29 \\
\hline & $1-5 c$ & 1.967 & 0.653 & 0.856 & 0.001 & 0.259 & 0.007 & 0.001 & 0.12 & 0.133 & 0.00 & 0.002 & 28.44 \\
\hline & $2-6 c$ & 1.964 & 0.665 & 0.896 & 0.00 & 0.259 & 0.009 & 0.000 & 0.095 & 0.108 & 0.00 & 0.004 & 28.03 \\
\hline & $3-8 r$ & 1.962 & 0.636 & 0.839 & 0.001 & 0.258 & 0.006 & 0.000 & 0.139 & 0.156 & 0.00 & 0.003 & 28.86 \\
\hline & $3-9 c$ & 1.961 & 0.661 & 0.888 & 0.006 & 0.268 & 0.008 & 0.001 & 0.095 & 0.111 & 0.00 & 0.001 & 28.88 \\
\hline & $3-10 r$ & 1.941 & 0.668 & 0.888 & 0.00 & 0.268 & 0.008 & 0.000 & 0.107 & 0.117 & 0.00 & 0.004 & 28.64 \\
\hline
\end{tabular}

Note. $\mathrm{r}$ - grain rim, $\mathrm{c}-$ grain center, $f=\mathrm{Fe} \times 100 \% /(\mathrm{Fe}+\mathrm{Mg})-$ ferruginosity.

Institute of Geology and Geochemistry, Ural Branch of the Russian Academy of Sciences; analyst D. V. Kiselyova.

Distribution spectra of REEs in the CMZ amphibolites are flat (Fig. 4), 10-20 times higher than chondritic, with a slight predominance of heavy lanthanides. The Europium anomaly is usually absent.

It should be noted that the distribution spectra of REE in amphiboles are similar to those in the rock, with the exception of a sharp enrichment of La in the sample of garnet-free pyroxene-bearing amphibolite (number of sample Y-3536/3; Fig. 4, d). The sharp jump in La can be explained by the "contamination" of the sample with epidote, which is known to concentrate light and medium REE [14]. In amphiboles from samples of porphyroblastic garnet amphibolites (number of sample Y-3533/1, Y-3536/1; Fig. 4 a, c), there is a negative europium anomaly.

The REE distribution spectra in garnets have a steep positive slope due to the predominance of heavy and medium lanthanides over light ones. There is no europium anomaly, which is observed in all metamorphic garnets with high calcium content. An increase in calcium in garnets leads to a gradual decrease and then to the disappearance of the negative Eu anomaly, since the incorporation of large $\mathrm{Ca}^{2+}$ ions makes it easier to fill the position with larger $\mathrm{Eu}^{2+}$ ions compared to other REEs [13].

\section{Conclusion}

The high contents of REE in garnet amphibolites, primarily heavy ones, are associated with the predominant accumula- 
a

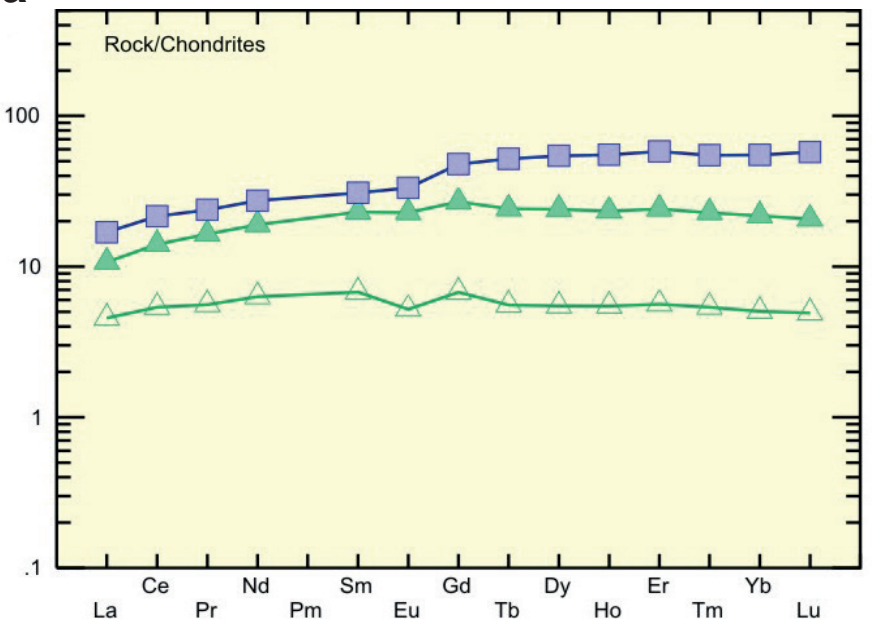

$\triangle \mathrm{Y}-3533 / 1 \mathrm{amp} ; \square \mathrm{Y}-3533 / 1 \mathrm{gr} ; \Delta \mathrm{Y}-3533 / 1$ b

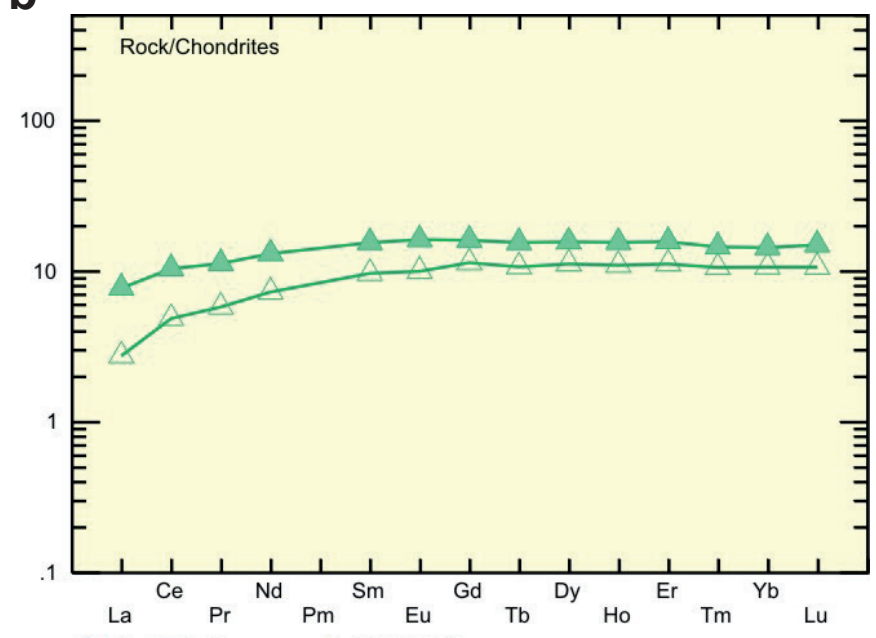

$\triangle \mathrm{y}-3533 / 3$ amp; $\Delta \mathrm{Y}-3533 / 3$

d

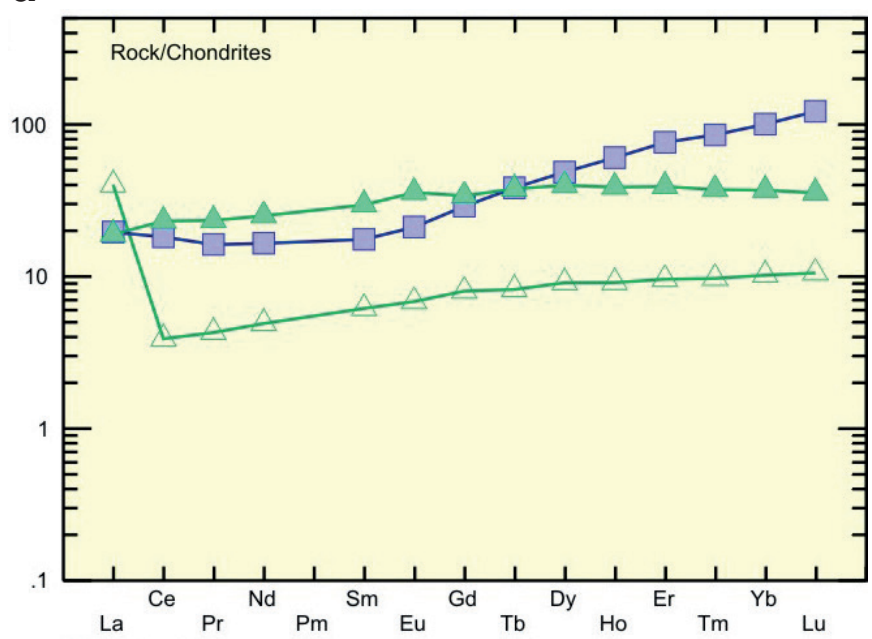

$\triangle \mathrm{Y}-3536 / 3 \mathrm{amp} ; \square \mathrm{y}-3536 / 3 \mathrm{gr} ; \Delta \mathrm{Y}-3536 / 3$
C

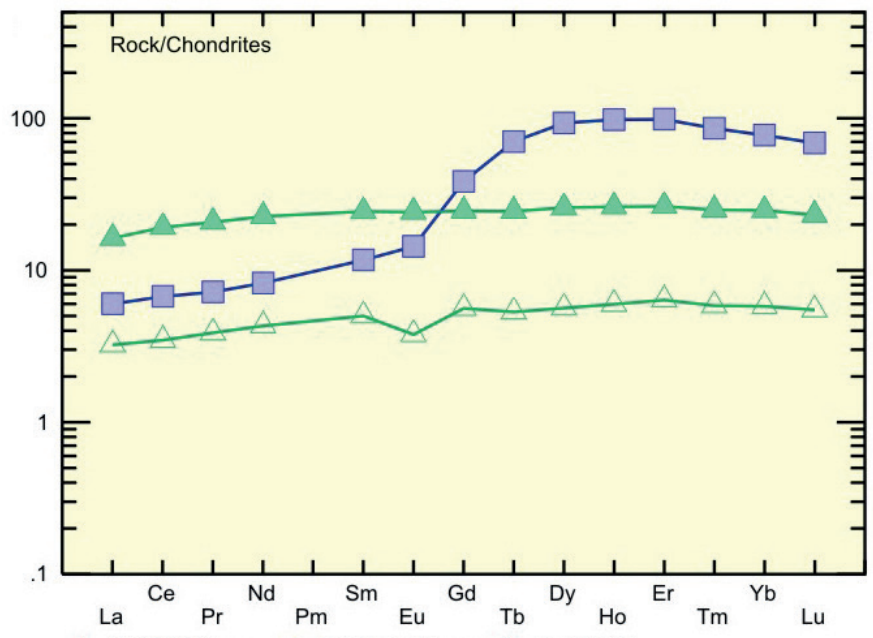

$\triangle$ Y-3536/1 amp; $\square$ Y-3536/1 gr; $\triangle$ Y-3536/1

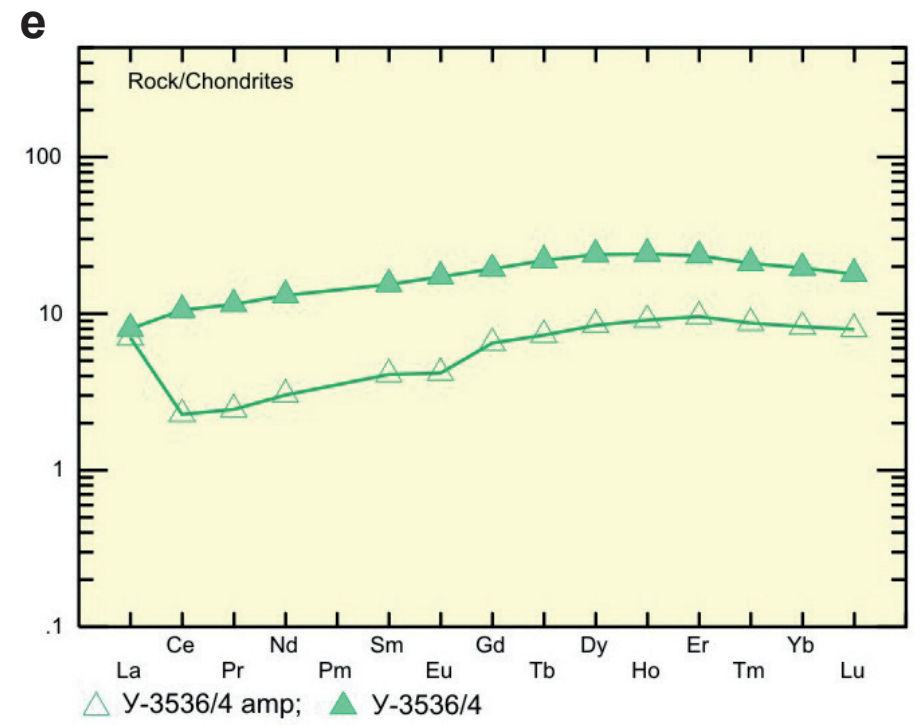

$\triangle \mathrm{Y}-3536 / 4 \mathrm{amp} ; \quad \triangle \mathrm{Y}-3536 / 4$

Figure 4. REE distribution spectra in amphibolites and main rock-forming minerals (amp - amphibole; gr - garnet).

Рисунок 4. Спектры распределения Р3Э в амфиболитах и главных породообразующих минералах (amp - aмфибол; gr - гранат). 
Table 4. Chemical composition of garnet from amphibolite, wt. \%.

Таблица 4. Химический состав граната из амфиболита, мас. \%.

\begin{tabular}{|c|c|c|c|c|c|c|c|c|c|c|c|}
\hline $\begin{array}{l}\text { Number } \\
\text { of sample }\end{array}$ & Grain-point & $\mathrm{SiO}_{2}$ & $\mathrm{TiO}_{2}$ & $\mathrm{Al}_{2} \mathrm{O}_{3}$ & $\mathrm{Cr}_{2} \mathrm{O}_{3}$ & $\mathrm{FeO}$ & $\mathrm{MgO}$ & $\mathrm{MnO}$ & $\mathrm{CaO}$ & $\mathrm{Na}_{2} \mathrm{O}$ & Total \\
\hline \multirow{12}{*}{ Y-3533/1 } & $5-65 c$ & 38.43 & 0.17 & 20.77 & 0.00 & 24.70 & 3.02 & 1.95 & 11.62 & 0.05 & 100.71 \\
\hline & $5-66 c$ & 38.54 & 0.14 & 20.87 & 0.02 & 25.14 & 3.02 & 1.89 & 10.78 & 0.02 & 100.42 \\
\hline & $6-69 k$ & 38.03 & 0.12 & 20.62 & 0.13 & 25.53 & 2.54 & 0.60 & 11.47 & 0.04 & 99.08 \\
\hline & $6-70 \mathrm{k}$ & 37.87 & 0.13 & 20.69 & 0.06 & 26.23 & 2.74 & 0.6 & 11.00 & 0.05 & 99.37 \\
\hline & $6-71 \mathrm{k}$ & 38.39 & 0.17 & 20.90 & 0.08 & 24.43 & 3.26 & 1.62 & 10.88 & 0.00 & 99.73 \\
\hline & \multicolumn{11}{|c|}{ Formula coefficients (converted to 8 cations) } \\
\hline & Grain-point & $\mathrm{Si}$ & $\mathrm{Ti}$ & $\mathrm{Al}$ & $\mathrm{Cr}$ & $\mathrm{Fe}$ & $\mathrm{Mg}$ & $\mathrm{Mn}$ & $\mathrm{Ca}$ & $\mathrm{Na}$ & Alm, \% \\
\hline & $5-65 c$ & 3.004 & 0.010 & 1.913 & 0.000 & 1.615 & 0.352 & 0.129 & 0.973 & 0.004 & 51.51 \\
\hline & $5-66 c$ & 3.024 & 0.008 & 1.930 & 0.001 & 1.650 & 0.353 & 0.126 & 0.906 & 0.002 & 54.23 \\
\hline & $6-69 k$ & 3.027 & 0.007 & 1.934 & 0.008 & 1.700 & 0.301 & 0.040 & 0.978 & 0.003 & 56.28 \\
\hline & $6-70 \mathrm{k}$ & 3.007 & 0.008 & 1.936 & 0.004 & 1.742 & 0.324 & 0.040 & 0.936 & 0.004 & 56.64 \\
\hline & $6-71 \mathrm{k}$ & 3.025 & 0.010 & 1.941 & 0.005 & 1.610 & 0.383 & 0.108 & 0.918 & 0.000 & 53.32 \\
\hline
\end{tabular}

Note. $\mathrm{K}$ - grain edge, $\mathrm{C}$ - grain center, Alm - almandine component.

Table 5. P-T-parameters of amphibolite formation and peculiarities of amphibole composition. Таблица 5. Р-Т-параметры образования амфиболитов и особенности состава амфиболов.

\begin{tabular}{|c|c|c|c|c|c|c|}
\hline $\begin{array}{l}\text { Number } \\
\text { of sample }\end{array}$ & $\begin{array}{c}T,{ }^{\circ} \mathrm{C} \text {, according to the } \\
\text { amphibole-plagioclase } \\
\text { geothermometer by } \\
\text { T. Holland, J. Blundy } \\
\text { (1994) }\end{array}$ & $\begin{array}{c}T,{ }^{\circ} \mathrm{C}, \\
\text { according to the } \\
\text { garnet amphibole } \\
\text { geothermometer } \\
\text { by L. L. Perchuk } \\
\text { (1990) }\end{array}$ & $\begin{array}{l}P, \text { kbar, according } \\
\text { to amphibole geo- } \\
\text { barometer by M. W. } \\
\text { Schmidt (1992) }\end{array}$ & $\begin{array}{l}\text { The sum } \\
\text { of REE } \\
\text { in } \\
\text { amphibole, } \\
\text { ppm }\end{array}$ & $\begin{array}{c}\mathrm{TiO}_{2} \\
\text { in amphibole, } \\
\text { wt. \% }\end{array}$ & $\begin{array}{c}(\mathrm{La} / \mathrm{Yb})_{\mathrm{n}} \\
\text { in amphibole }\end{array}$ \\
\hline Y-3533/1 & $683.3-696.1$ & 598.3-619.3 & $9.3-10.1$ & 14.52 & 0.96 & 1.26 \\
\hline Y-3536/4 & $565.4-663.7$ & - & $6.3-7.1$ & 13.12 & 0.67 & 1.19 \\
\hline
\end{tabular}

tion of garnets in the crystal structure, which is characterized by a relatively small unit cell size [15].

The value of $(\mathrm{La} / \mathrm{Yb})_{\mathrm{n}}$ in amphibolites is $0.39-0.62 \mathrm{ppm}$. The total REE content is in the range of $33-75 \mathrm{ppm}$. The variation in the amount of REE within one rock is associated with the quantitative content of the main concentrating minerals. The main mineral concentrator of lanthanides in garnet amphibolites is garnet: the total content of REE is $86-89 \mathrm{ppm}$, while amphibole concentrates 12-25 ppm of lanthanides. In garnet-free pyroxene-bearing amphibolites, amphibole is the main concentrating mineral; the REE content is 13-20 ppm.

Based on the results of the chemical composition of amphibole and coexisting plagioclases and amphibolite garnets, the temperature was calculated using amphibole-plagioclase by T. Holland, J. Blundy [16], as well as the garnet amphibious by L. L. Perchuk [17] geothermometers and pressure based on amphibole geobarometer by M. W. Schmidt [18, Table 5]. For amphibole made of garnet amphibolite of sample Y-3533/1 calculated pressure was 9.3-10.1 kbar, temperature - 683.3-696.1 ${ }^{\circ} \mathrm{C}$ (according to T. Holland, J. Blundy [16]), 598.3-619.3 ${ }^{\circ} \mathrm{C}$ (by L. L. Perchuk [17]). For amphibole from garnet-free pyroxene-containing amphibolite number of sample Y-3536/4 calculated pressure was 6.3-7.1 kbar, temperature - 565.4-663.7 ${ }^{\circ} \mathrm{C}$ (according to T. Holland, J. Blundy [16]). The parameters correspond to the amphibolite facies of metamorphism. Thus, a comparison of the parameters and compositional features of amphiboles from amphibolites suggests a direct relationship between temperature, pressure and the amount of REE, (La/ $\mathrm{Yb})_{\mathrm{n}}$, as well as $\mathrm{TiO}_{2}$. According to S. G. Skublov, with an increase in the temperature of metamorphism, the total concentration of REE in amphiboles increases [14], which is reflected in the results of the study presented in this work.

The work was performed within state assignment of the Zavaritsky Institute of Geology and Geochemistry of the Ural Branch of the Russian Academy of Sciences, no. AAAA-A18-118052590032-6.

\section{REFERENCES}

1. Perevozchikov B. V., Kenig V. V., Lukin A. A., Ovechkin A. M. 2005, Chromites of the Ray-Iz massif in the polar Urals. Geologiya rudnykh mestorozhdeniy [Geology of ore deposits], vol. 47, no. 3, pp. 230-248. (In Russ.)

2. Zavaritsky A. N. 1932, Peridotitovyy massiv Ray-Iz v Polyarnom Urale [Ray-Iz peridotite massif in the Polar Ural]. Moscow, $221 \mathrm{p}$.

3. Tsaritsyn E. P., Alimov V. Yu., Sherstobitova L. A., Yablonskaya L. V. 1981, Metamorphism of Cr-spinels in hyperbasites of the Ray-Iz massif. Yearbook-1980, pp. 109-111.

4. Moldavantsev Yu. E., Berlyand N. G., Kazak A. P. 1977, Razrez zemnoy kory Polyarnogo Urala po geofizicheskim dannym [Section of the earth's crust of the Polar Urals according to geophysical data]. Leningrad, pp. 85-91. 
5. Makeev A. B., Perevozchikov B. V., Afanasyev A. K. 1985, Khromitonosnost' Polyarnogo Urala [Chromite content of the Polar Ural]. Syktyvkar, 152 p. 6. Chashchukhin I. S., Perevozchikov B. V., Tsaritsyn E. P. 1986, Metamorphism of hyperbasites of the Ray-Iz massif (Polar Ural). Research on Petrology and metallogeny of the Urals. Sverdlovsk, pp. 49-75.

7. Puchkov V. N., Steinberg D. S. 1990, Stroyeniye, evolyutsiya i minerageniya giperbazitovogo massiva Ray-Iz [Structure, evolution, and mineralogy of the Ray-Iz hyperbasite massif]. Sverdlovsk, $228 \mathrm{p}$.

8. Vakhrusheva N. V., Shiryaev P. B., Stepanov A. E., Bogdanova A. R. 2017, Petrologiya i khromitonosnost' ul'traosnovnogo massiva Ray-lz (Polyarnyy Ural) [Petrology and chromite content of the Ray-lz ultrabasic massif (Polar Ural)]. Ekaterinburg, $265 \mathrm{p}$.

9. 2009, Petrographic Code of Russia. Saint Petersburg, 194 p.

10. Hawthorne F. C., Oberti R., Harlow G. E., Maresch W. V., Martin R. F., Schumacher J. C., Welch M. D. 2012, Nomenclature of the amphibole supergroup. American Mineralogist, vol. 97, number 11-12, pp. 2031-2048. https://doi.org/10.2138/am.2012.4276

11. Leake B. E., Woolley A. R., Arps C. E. S., Birch W. D., Gilbert M. C., Grice J. D., Hawthorne F. C., Kato A., Kisch H. J., Krivovichev V. G., Linthout K., Laird J., Mandarino J. A., Maresch W. V., Nickel E. H., Rock N. M. S., Schumacher J. C., Smith D. C., Stephenson N. C. N., Ungaretti L., Whittaker E. J. W., Youzhi G. 1997, Nomenclature of amphiboles: report of the subcommittee on amphiboles of the international mineralogical association, commission on new minerals and mineral names. Canadian Mineralogist, vol. 35, number 1, pp. 219-246. https://doi.org/10.1180/ minmag.1997.061.405.13

12. Morimoto N., Fabries J., Ferguson A. K., Ginzburg I. V., Ross M., Seifert F. A., Zussman J., Aoki K., Gottardi G. 1988, Nomenclature of pyroxenes. Mineralogical Magazine, vol. 52, issue 367, pp. 535-550. https://doi.org/10.1180/minmag.1988.052.367.15

13. Skublov S. G., Drugova G. M. 2004, Peculiarities of distribution of rare earth elements in metamorphic minerals. Vestnik Sankt-Peterburgskogo universiteta [Vestnik of St. Petersburg University], ser. 7, issue 1 (no. 7), pp. 68-71. (In Russ.)

14. Skublov S. G. 2005, Geokhimiya redkozemel'nykh elementov v porodoobrazuyushchikh metamorficheskikh mineralakh [Geochemistry of rare earth elements in rock-forming metamorphic minerals]. Saint Petersburg, $147 \mathrm{p}$.

15. Lesnov F. P. 2009, Redkozemel'nyye elementy v ul'tramafitovykh i mafitovykh porodakh i ikh mineralakh [Rare-earth elements in ultramafic and mafic rocks and their minerals]. Book 2. Secondary and accessory minerals. Novosibirsk, $190 \mathrm{p}$.

16. Holland T., Blundy J. 1994, Non-ideal interactions in calcic amphiboles and their bearing on amphibole-plagioclase thermometry. Contrib. Mineral. Petrol., vol. 116, pp. 433-447. https://doi.org/10.1007/bf00310910

17. Perchuk L. L. 1990, Derivation of termodynamically consistent system of geothermometers and geobabarometers for metamorphic and magmatic rocks. In: Progress in metamorphic and magmatic petrology. Cambridge: Cambridge University Press, pp. 93-112. https://doi. org/10.1017/CBO9780511564444.007

18. Schmidt M. W. 1992, Amphibole composition in tonalite as a function of pressure: an experimental calibration of the Al-in-hornblende barometer. Contrib. Mineral. Petrol., vol. 110, pp. 304-310. https://doi.org/10.1007/BF00310745 


\title{
Главные и редкоземельные элементы амсриболитов массива Рай-Из (Полярный Урал)
}

\author{
Алена Романовна БОГДАНОВА ${ }^{1 *}$, \\ Надежда Владимировна ВАХРУШЕВА ${ }^{1,2 * *}$, \\ Павел Борисович ШИРЯЕВ ${ }^{1,2 * * *}$
}

${ }^{1}$ Институт геологии и геохимии им. А. Н. Заварицкого УрО РАН, Екатеринбург, Россия

2Уральский государственный горный университет, Екатеринбург, Россия

Аннотация

Актуальность. Массив Рай-Из вмещает месторождение хромовых руд Центральное и уникален по разнообразию представленных в нем породных метаморфических ассоциаций. Его изучение ведется с 1932 г. и продолжается до сих пор. Однако отдельные аспекты геологии и петрологии в литературе освещены недостаточно полно. Одной из таких областей является жильная серия пород, локализованная в ультрамафитах. Пространственная приуроченность амфиболитов к Центральной зоне метаморфизма, которая согласна с полосой распространения месторождений и рудопроявлений хромитов, определяет необходимость детального исследования.

Цель работы. Исследование минералого-петрографических характеристик, а также геохимии лантаноидов амфиболитов массива Рай-Из (Полярный Урал).

Результаты. Изучение характера распределения РЗЭ в породообразующих минералах позволило установить, что вариация суммы Р3Э (33-75 г/т) в пределах одной породы связана с количественным содержанием главных минералов-концентраторов. Главным минералом-концентратором лантаноидов в гранатовых амфиболитах является гранат, тогда как в безгранатовых пироксенсодержащих амфиболитах амфибол. На основе результатов химического состава амфиболов и сосуществующих с ними плагиоклазов и гранатов амфиболитов выполнены расчеты температуры по амфибол-плагиоклазовому (T. Holland, J. Blundy), а также по гранат-амфиболовому (L. L. Perchuk) геотермометрам и давления по амфиболовому геобарометру (M.W. Schmidt).

Bывод. Выявлен характер распределения лантаноидов в главных породообразующих минералах - амфиболе и гранате. Сравнение параметров и особенностей состава амфиболов позволило сделать вывод о прямой зависимости между температурой, давлением, суммой Р3Э и $\mathrm{TiO}_{2}$, а также $(\mathrm{La} / \mathrm{Yb})_{\mathrm{n}}$ в минерале.

Ключевые слова: амфибол, амфиболит, геохимия РЗЭ, Центральная зона метаморфизма, Рай-Из, Полярный урал.

\section{ЛИТЕРАТУРА}

1. Перевозчиков Б. В., Кениг В. В., Лукин А. А., Овечкин А. М. Хромиты массива Рай-Из на Полярном Урале // Геология рудных месторождений. 2005. Т. 47, № 3. С. 230-248.

2. Заварицкий А. Н. Перидотитовый массив Рай-Из в Полярном Урале. М.; Л.: Гос. науч.-технич. геол.-развед. изд-во, 1932.221 с.

3. Царицын Е. П., Алимов В. Ю., Шерстобитова Л. А., Яблонская Л. В. Метаморфизм хромшпинелидов в гипербазитах массива Рай-Из // Ежегодник-1980. ИГГ УНЦ АН СССР. Свердловск, 1981. С. 109-111.

4. Молдаванцев Ю. Е., Берлянд Н. Г., Казак А. П. Разрез земной коры Полярного Урала по геофизическим данным. Л.: ВСЕГЕИ, 1977. C. 85-91.

5. Макеев А. Б., Перевозчиков Б. В., Афранасьев А. К. Хромитоносность Полярного Урала. Сыктывкар: Коми фил. АН СССР, 1985.152 с. 6. Чащухин И. С., Перевозчиков Б. В., Царицын Е. П. Метаморфизм гипербазитов массива Рай-Из (Полярный Урал) // Исследования по петрологии и металлогении Урала. Свердловск, 1986. С. 49-75.

7. Строение, эволюция и минерагения гипербазитового массива Рай-Из / под ред. В. Н. Пучкова и Д.С. Штейнберга. Свердловск: УрО АН CCCP. 1990. 228 c.

8. Вахрушева Н. В., Ширяев П. Б., Степанов А. Е., Богданова А. Р. Петрология и хромитоносность ультраосновного массива Рай-Из (Полярный Урал). Екатеринбург: ИГГ УрО РАН, 2017. 265 с.

9. Петрографический кодекс России. СПб.: Изд-во ВСЕГЕИ, 2009. 194 с.

10. Hawthorne F. C., Oberti R., Harlow G. E., Maresch W. V., Martin R. F., Schumacher J. C., Welch M. D. Nomenclature of the amphibole supergroup // American Mineralogist. 2012. Vol. 97, № 11-12. P. 2031-2048. https://doi.org/10.2138/am.2012.4276

11. Leake B. E., Woolley A. R., Arps C. E. S., Birch W. D., Gilbert M. C., Grice J. D., Hawthorne F. C., Kato A., Kisch H. J., Krivovichev V. G., Linthout K., Laird J., Mandarino J. A., Maresch W. V., Nickel E. H., Rock N. M. S., Schumacher J. C., Smith D. C., Stephenson N. C. N., Ungaretti L., Whittaker E. J. W., Guo Y. Nomenclature of amphiboles // Canadian Mineralogist. 1997. Vol. 35. № 1. P. 219-246. https://doi.org/10.1180/ minmag.1997.061.405.13 
12. Morimoto N., Fabries J., Ferguson A. K., Ginzburg I. V., Ross M., Seifert F. A., Zussman J., Aoki K., Gottardi G. Nomenclature of pyroxenes // Mineralogical Magazine. 1988. Vol. 52, issue 367. P. 535-550. https://doi.org/10.1180/minmag.1988.052.367.15

13. Скублов С. Г., Другова Г. М. Особенности распределения редкоземельных элементов в метаморфических минералах // Вестник СПбГУ. 2004. Сер. 7. Вып. 1 (№ 7). С. 68-71.

14. Скублов С. Г. Геохимия редкоземельных элементов в породообразующих метаморфических минералах. СПб.: Наука, 2005.147 с.

15. Леснов Ф. П. Редкоземельные элементы в ультрамафитовых и мафитовых породах и их минералах. Кн. 2. Второстепенные и акцессорные минералы. Новосибирск: Академ. Изд-во «ГЕО», 2009. 190 с.

16. Holland T., Blundy J. Non-ideal interactions in calcic amphiboles and their bearing on amphibole-plagioclase thermometry // Contrib. Mineral. Petrol. 1994. Vol. 116. P. 433-447. https://doi.org/10.1007/bf00310910

17. Perchuk L. L. Derivation of termodynamically consistent system of geothermometers and geobabarometers for metamorphic and magmatic rocks // Progress in metamorphic and magmatic petrology. Cambridge: Cambridge University Press, 1990. P. 93-112. https://doi.org/10.1017/ СВО9780511564444.007

18. Schmidt M. W. Amphibole composition in tonalite as a function of pressure: an experimental calibration of the Al-in-hornblende barometer // Contrib. Mineral. Petrol. 1992. Vol. 110. P. 304-310. https://doi.org/10.1007/BF00310745

Статья поступила в редакцию 8 сентября 2020 года 